G.V. Bezprozvannych, I.A. Kostiukov

\title{
A METHOD OF WAVELET ANALYSIS OF TIME SERIES OF PARAMETERS OF DIELECTRIC ABSORPTION OF ELECTRICAL INSULATING STRUCTURES
}

Introduction. In the objects of control there are always a number of interfaces, for example, solid insulation - electrode. On contacting surfaces, free surface charges are transferred. Surface conductivity leads to fluctuations in the measured values of the capacitance and the tangent of the dielectric loss angle of solid insulation, the state of which is determined. The drain off of the surface charge does not lead to a decrease in the scatter of the measured dielectric absorption parameters. One of the main reasons for the significant time spread of the dielectric absorption parameters, and to a large extent (three orders of magnitude) of the dielectric loss tangent are tribo charges caused by triboelectrification of cable structural elements. Tribo charges cause internal noise in electrical insulating structures, masking processes in the polymer insulation itself. Purpose. Substantiation of a method for analyzing the time series of dielectric absorption parameters, which provides increased accuracy of control and diagnostics of solid polymer insulation of electrical insulation structures based on filtering experimental data using wavelet transform. Methodology. The inefficiency of filtering the spectra of time series using a low filter based on the direct Fourier transform is shown. Multilevel wavelet decomposition of the time series of parameters is presented, and the efficiency of applying wavelet transforms to identify high-frequency and low-frequency components in the measured values. Practical value. The method of analyzing the time series of dielectric absorption parameters using the wavelet transform, proposed for the first time, makes it possible to increase the accuracy of monitoring and diagnostics of solid polymer insulation both at the manufacturing stage and in the operation of electrical insulating structures. This method is the basis for creating a database of control results for assessing the state of solid polymer insulation of electrical insulation structures, in particular, power and information cables. References 17, figures 8.

Key words: dielectric absorption parameters, capacitance, dielectric loss tangent, spectrum of time series, low-pass filter, decomposition levels, approximation and detail, wavelet transform.

Встановлено вплив поверхневих і трібозарядов на результати контролю смності і тангенса кута діелектричних втрат екранованих і неекранованих кабелів з полімерною ізоляцією. Показана неефективність фільтрації спектрів часових рядів за допомогою фільтра низьких частот на основі прямого перетворення Фур'є. На прикладі неекранованого кабелю представлено багаторівневе вейвлет розкладання часових рядів параметрів $і$ показана ефективність застосування вейвлет перетворення для виявлення високочастотних $і$ низькочастотних компонент у виміряних значеннях. Обтрунтовано оптимальний рівень розкладання параметрів діелектричної абсорбції неекранованого $і$ екранованого кабелів за допомогою вейвлета Добиші 12 порядку. Доведено ефективність методу вейвлет аналізу часових рядів параметрів діелектричної абсорбцї щодо підвищення точності контролю та діагностики твердої полімерної ізоляції електроізоляційних конструкцій. Бібл. 17, рис. 8.

Ключові слова: параметри діелектричної абсорбції, смність, тангенс кута діелектричних втрат, спектр часових рядів, фільтр низьких частот, рівні розкладання, апроксимація та деталізація, вейвлет перетворення.

Установлено влияние поверхностных и трибозарядов на результаты контроля емкости и тангенса угла диэлектрических потерь экранированных и неэкранированных кабелей с полимерной изоляцией. Показана неэффективность фильтрации спектров временных рядов с помощью фильтра низких частот на основе прямого преобразования Фурье. На примере неэкранированного кабеля представлено многоуровневое вейвлет разложение временных рядов параметров и показана эффективность применения вейвлет преобразования для выявления высокочастотных и низкочастотных компонент в измеренных значениях. Обоснован оптимальный уровень разложения параметров диэлектрической абсорбции неэкранированного и экранированного кабелей с помощью вейвлета Добиши 12 порядка. Показана эффективность метода вейвлет анализа временных рядов параметров диэлектрической абсорбци, обеспечивающего повыщение точности контроля и диагностики твердой полимерной изоляции электроизоляционных конструкций. Библ. 17, рис. 8.

Ключевые слова: параметры диэлектрической абсорбции, емкость, тангенс угла диэлектрических потерь, спектр временных рядов, фильтр низких частот, уровни разложения, аппроксимация и детализация, вейвлет преобразование.

Introduction. Monitoring and diagnostics of electrical insulating structures with high-quality solid polymer insulation according to dielectric absorption parameters requires equipment with increased sensitivity and high selectivity of measurements [1-4]. In the objects of control there are always a number of interfaces, for example, insulation - electrode, insulation - insulation. On contacting surfaces, free surface charges are transferred. Surface conductivity leads to fluctuations in the measured values of the capacitance and the tangent of the dielectric loss angle of solid insulation, the state of which is determined. Surface conductivity causes its own internal noise, significantly affecting the control results [4]. To reduce the effect of surface charges, all currentcarrying parts of the structure are grounded before measurements. The time required for the surface charge to drain off is commensurate with the self-discharge time constant of the insulation [4]. 
Problem definition. The drain of the surface charge does not lead to a decrease in the scatter of the measured dielectric absorption parameters (Fig. 1). Figure 1 shows the results of measurements of the electric capacitance (Fig. 1,a) and the dielectric loss tangent (Fig. 1,b) of a shielded single-core power high-voltage cable: curves 1 correspond to measurements without draining surface charges; curves 2 - with a charge drain. The measurements were performed at frequency of $120 \mathrm{~Hz}$, for which the effect of free charge carriers on the measurement results is most pronounced in comparison with the data obtained at frequency of $1 \mathrm{kHz}$ [4].
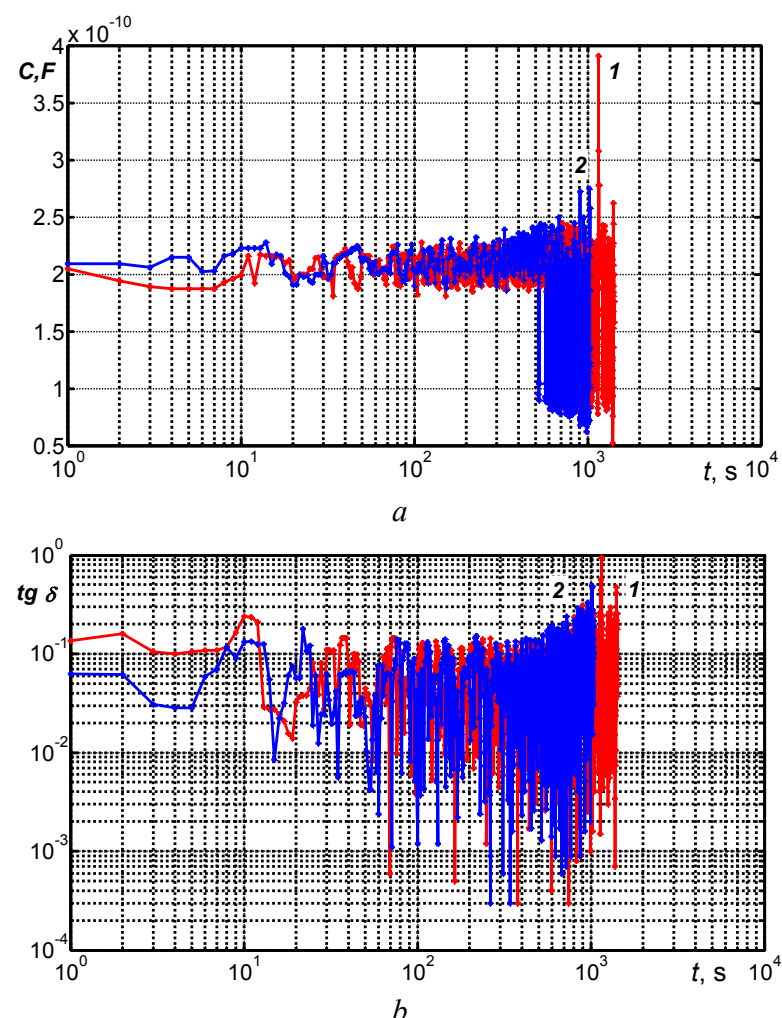

Fig. 1. The effect of drain off of surface charges on dielectric absorption parameters in the power cable

Obviously, one of the main reasons for the significant time spread of the dielectric absorption parameters, and to a large extent (three orders of magnitude) of the dielectric loss tangent (see Fig. 1,b), are tribo charges caused by triboelectrification of cable structural elements $[5,6]$ which is confirmed by the results of measurements of the contact potential difference (Fig. 2) [5-7]. The registration of the contact potential difference is the base of the diagnostics of surface properties of polymer solid insulation of cables [4-7].

Due to the presence of tribo charges, a double electric layer arises [8], and hence an additional electric capacitance. The value of the additional capacity is determined by the electrophysical properties of the solid insulation, the state of its surface, the presence of impurities, etc. [8]. Tribo charges cause internal noise in electrical insulating structures, masking processes in the polymer insulation itself (see Fig. 3).

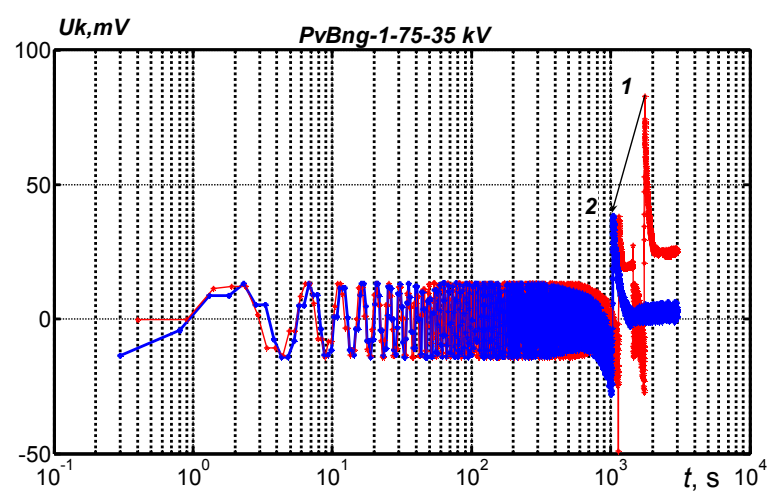

Fig. 2. Contact potential difference in the power cable with cross-linked polyethylene insulation before drain off (curve 1) and after drain off (curve 2) of surface charges
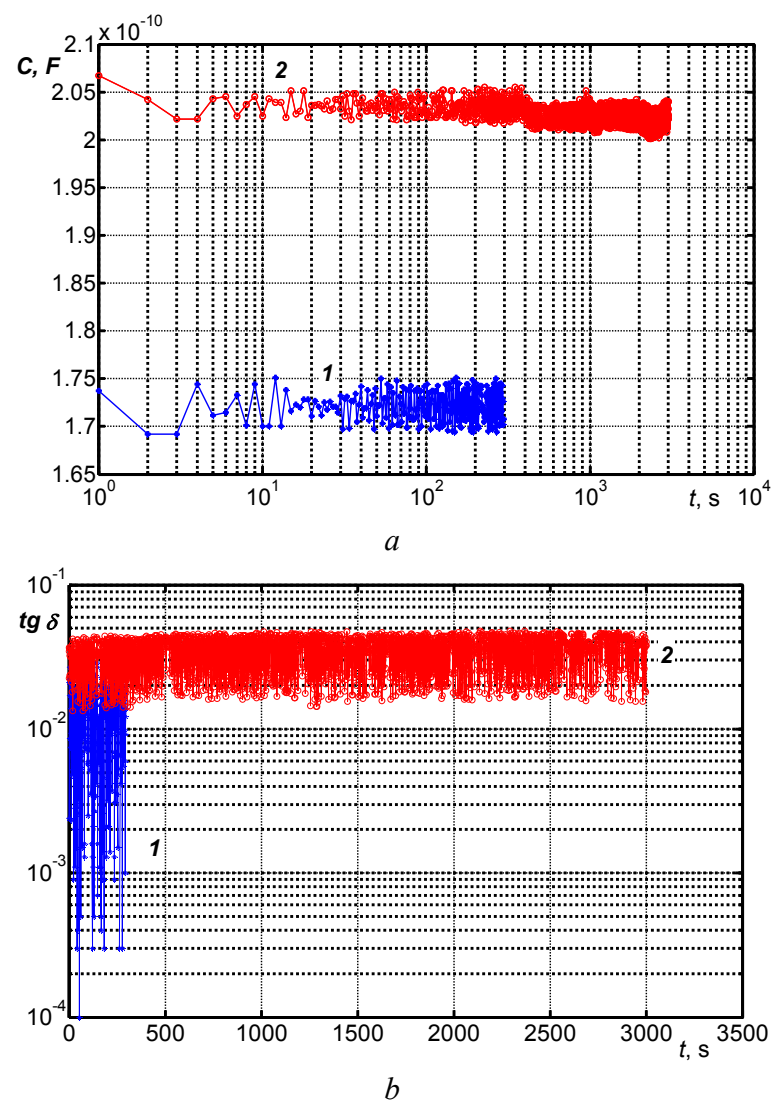

Fig. 3. The effect of tribo charges on the results of the control of polyethylene insulation by the electric capacity $(a)$ and the dielectric loss tangent $(b)$ in the initial state (curve 1) and after thermal radiation aging (curve 2) of the power cable

On the other hand, during long-term measurements, slow fluctuations of the results of measurements of the dielectric absorption parameters, i.e. flicker noise (Fig. 4), the more noticeable, the longer the observation interval $[4,6]$ are manifested. The regularity of such noise is the increase in amplitude inversely with the frequency (harmonic number $K$ ) (see Fig. 4). There is also thermal noise (Johnson noise) due to the thermal motion of charge carriers in the conductors of electrical insulating structures, resulting in a fluctuating potential difference at its ends [4].

The goal of the paper is substantiation of a method for analyzing the time series of dielectric absorption 
parameters, which provides increased accuracy of control and diagnostics of solid polymer insulation of electrical insulation structures based on filtering experimental data using wavelet transform.

Filtering the time series of dielectric absorption parameters using the Fourier transform. The presence of noise in the results of measurements of dielectric absorption parameters predetermines the mathematical processing of data using the direct and inverse Fourier transform [9-14].

The direct Fourier transform results in a spectral function (Fig. 4, 5). The Fourier transform is aimed at identifying the harmonic components of the time series, while the time series is decomposed into components in the form of sines and cosines. Then, a comparison is made of the studied sample and its response to the harmonic function by calculating the correlation. If, as a result of the comparison, it was found that there is a correlation, this means that the process contains components of the selected frequency. Then the frequency of the harmonic function changes, and the comparison procedure is repeated.
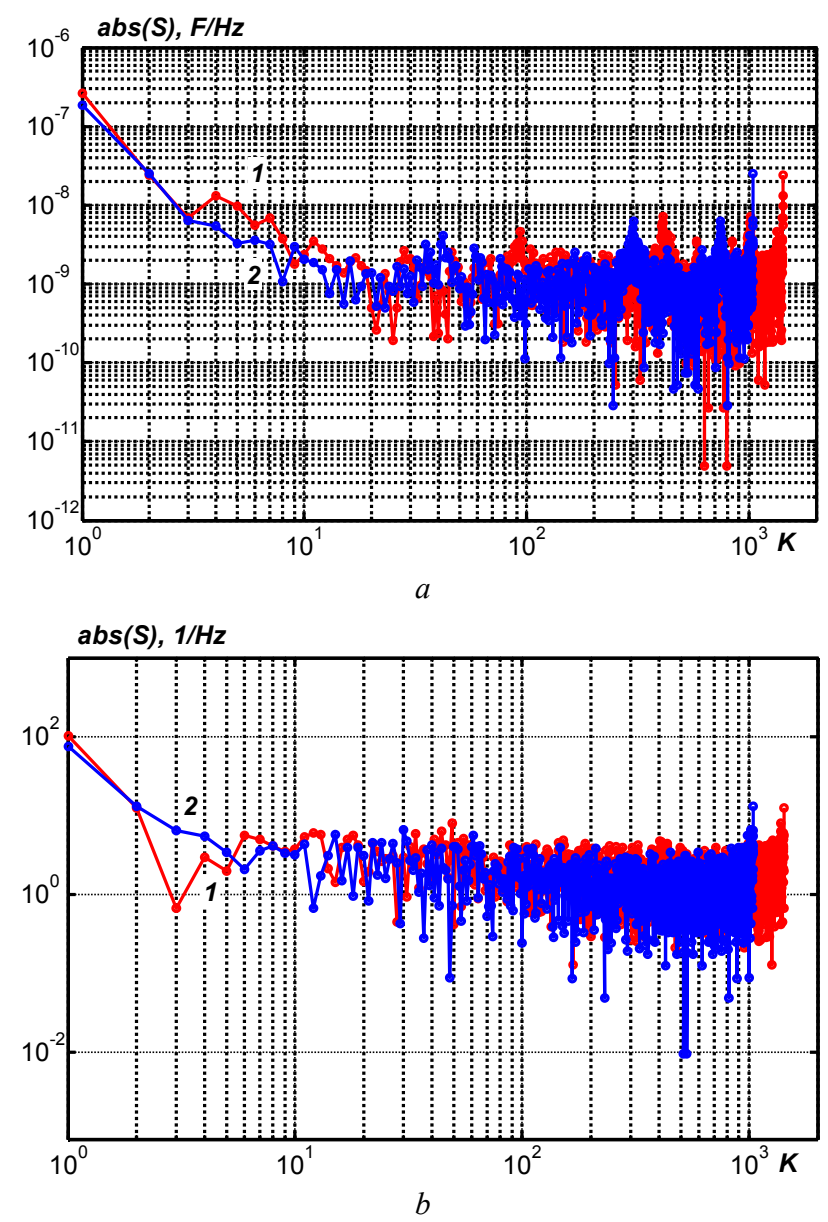

Fig. 4. Spectra of the electric capacitance $(a)$ and the dielectric loss tangent $(b)$ of the power cable with polyethylene crosslinked insulation before drain off (curve 1) and after drain off (curve 2) of surface charges

Figure 5 shows the time series of the dielectric absorption parameters of twisted pairs of unshielded
(Fig. 5,a) and shielded (Fig. 5,b) cables of category 5e. The spectra of the time series of the capacitance are presented in Fig. 6,a,c-curves 1 for unshielded (Fig. 6,a) and shielded (Fig. 6,c) cables, respectively. The spectra of the time series of the dielectric loss tangent are shown in Fig. 6,b,d - curves 1 for unshielded (Fig. 6,b) and shielded (Fig. 6,d) cables, respectively. Filtering the spectra of the time series of the dielectric absorption parameters using a low-pass filter of the 8th (curves 2), the 12th (curves 3 ) and 24th (curves 4) orders leads to a decrease in noise in the measurement results, but does not exclude the flicker component of noise and distorts the results, especially in the high-frequency region (see curves 1-4 in Fig. 6).
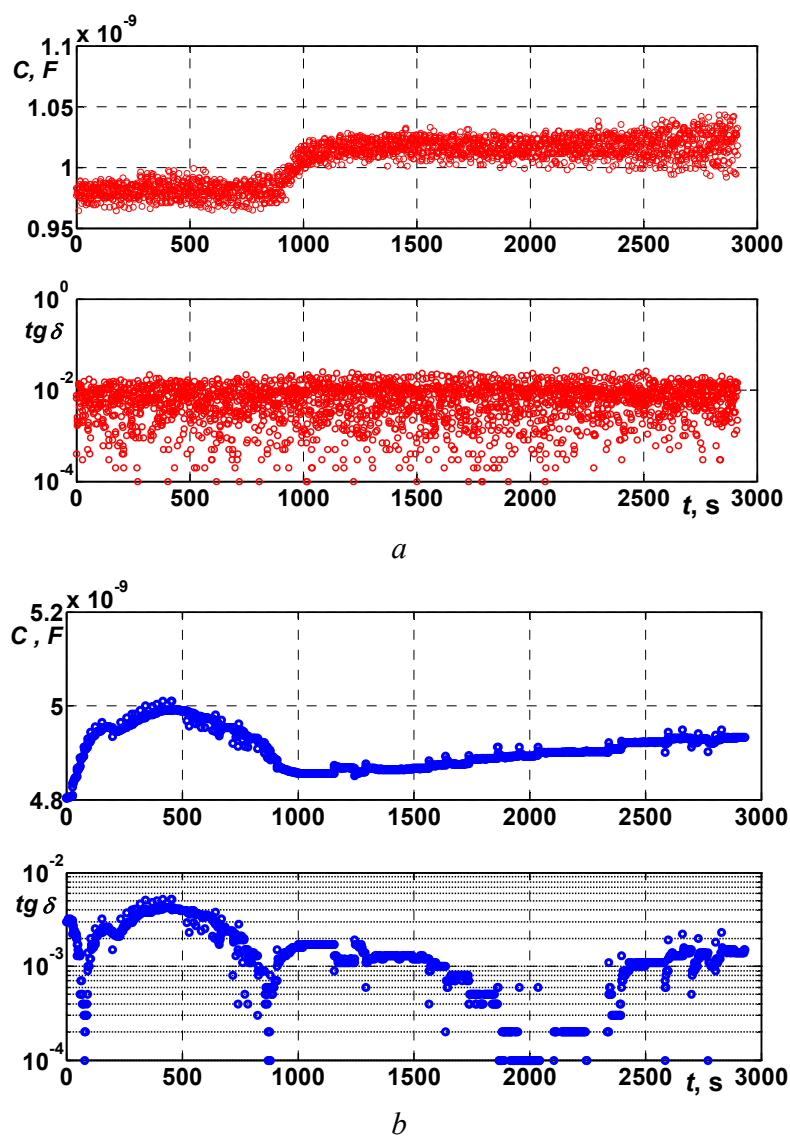

Fig. 5. Time series of parameters of dielectric absorption of twisted pairs of unshielded $(a)$ and shielded $(b)$ cables

Accurate restoration of the time series of dielectric absorption parameters after the direct and inverse Fourier transforms is practically impossible, in particular due to the appearance of the Gibbs effect - spreading of the spectrum [11-13]. The reason for the spreading of the spectrum is the lack of time localization of the sine and cosine functions used in the Fourier series.

To improve localization in time, for example, the window Fourier transform method is used. As the window functions, the Hanning, Blackman, Bartlett-Hann, Gaussian functions ( $S$-transform or Stockwell transform) are widely used [11-13]. But it is not possible to achieve at the same time high frequency and time resolution due to the Heisenberg uncertainty principle. 

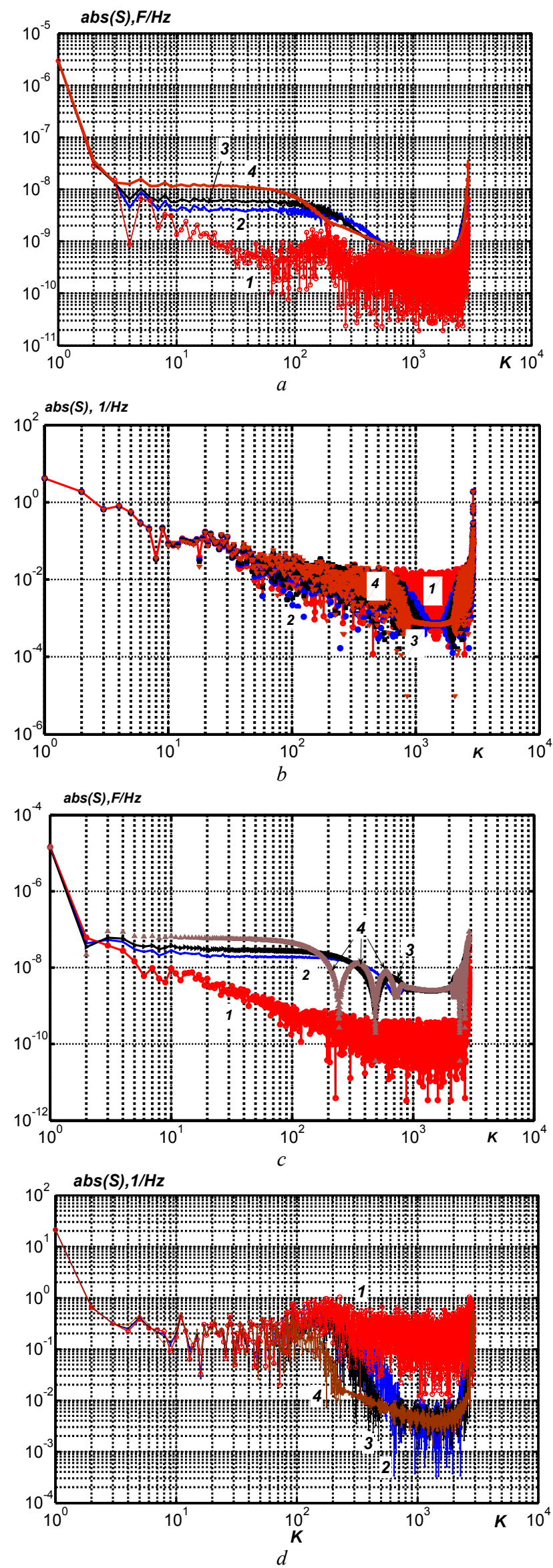

Fig. 6. On the efficiency of measured parameters filtration based on the direct Fourier transform
Approximation and detailing of time series of dielectric absorption parameters using wavelet transform. Considering that at certain points in time, the measured parameters (see Fig. 1, Fig. 3, 4) change stepwise, which leads to poor approximation by trigonometric functions, it becomes necessary to use other transforms, for example, wavelet transform $[14,15]$.

Figure 7 shows the process of a multi-level wavelet decomposition of time series of a capacitance (Fig. 7, $a, b$ for 4-level and 6-level decomposition, respectively) and the dielectric loss tangent (Fig. 7,c,d for 4-level and 6level decomposition, respectively) of unshielded cable based on twisted pairs (Fig. 5,a).

Such a decomposition process is a multiple alternation of subband filtering and a decrease in the number of samples. A halving of the number of samples means a halving of the quantization frequency, that is, a halving of the frequency scale (see Fig. 7). This is a common requirement for filters used in wavelet decomposition. On the left, approximations of time series (low-frequency components) are shown. On the right are the details (high-frequency). In MATLAB, a vector with approximation coefficients is denoted by $c A_{j}$, and a vector with detail coefficient is denoted by $c D_{j}$ [13]. The first part of the output vector is a set of half-sums of paired samples of time series and is a coarsened version of the original time series, which are "thinned out" twice in frequency, i.e. this is an approximation of the original time series. The second part is the half-differences of paired samples and is a set of complementary (detailing) information that is necessary to restore the original time series, i.e. detailing.

When restoring time series, first in the sequence of approximating and detailing coefficients zero elements are added, and then for each consequence its own filter is used to reconstruct the measured values.

Wavelet analysis of time series of dielectric absorption parameters of electrical insulating structures. The detection of local features or the allocation of individual sections in the experimental data is necessary at the stage of analysis. The wavelet transform provides extended information about the measurement results, which is achieved by filtering the initial data from random interferences, noise, outliers, non-linear distortions (see Fig. 7).

For a complete reconstruction of the time series of dielectric absorption parameters, only orthogonal wavelets with a compact carrier can be applied, for example, Daubechies family wavelets [16]. The advantage of this type of wavelets over others is that their use does not introduce additional redundancy in the initial data, and time series can be completely restored using quadrature mirror filters.

This type of wavelets is calculated using iterative expressions, and the form depends on the degree of the polynomial and the number of calculated coefficients $[14,15]$. 

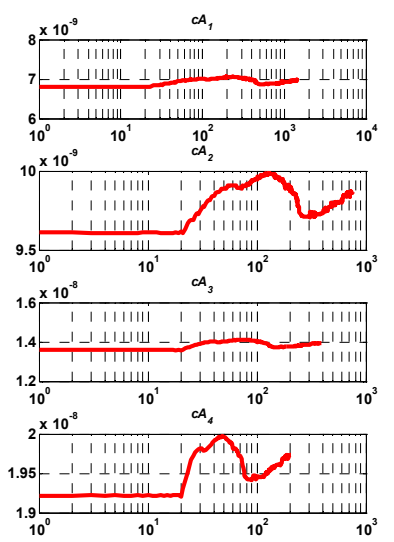

$a$

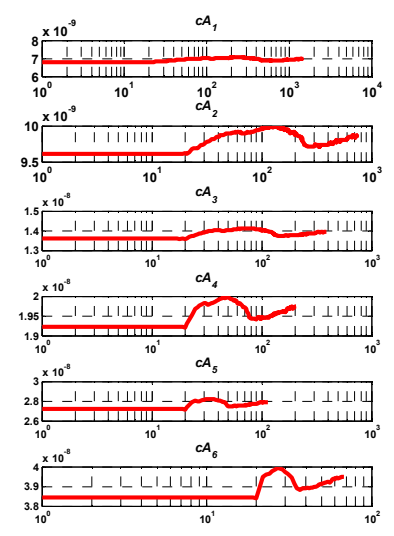

$b$
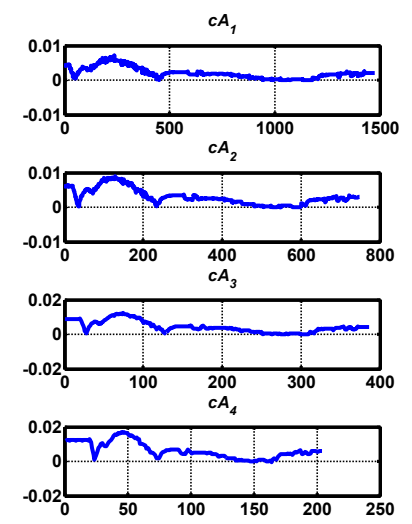

$c$
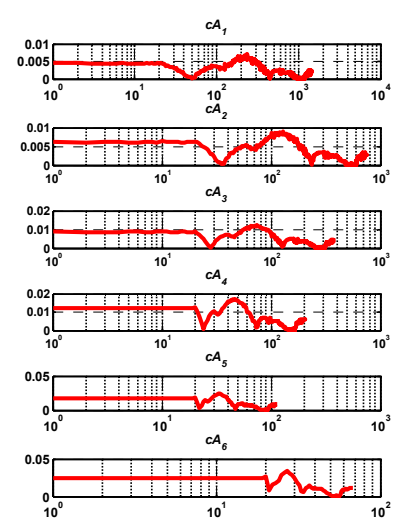

Fig. 7. Multilevel expansion using the Daubechies wavelet of the 12 th orders of the time series of dielectric absorption parameters
At high wavelet orders, the filter granularity increases, thereby filtering quality increases due to a steeper amplitude-frequency characteristic, but the computational volume at the transform also increases.

With a decrease in the order (window width) of the wavelet, the transform selects more and more highfrequency components, but the amplitude-frequency characteristic is more gentle (compare Fig. 7,c and Fig. 7,d).

Figure 8 shows the results of filtering the time series of the dielectric absorption parameters of twisted pairs of unshielded (Fig. 8,a,b) and shielded (Fig. 8,c,d) cables using a 12-order Daubechies wavelet with different levels of decomposition. Here, each level of decomposition is a filter that covers a certain range, regardless of the type of data being analyzed.

For an unshielded cable, the time series of the capacitance are presented in Fig. 8; of the dielectric loss tangent - in Fig. 8,b. The curves correspond to: 1 - initial data; 2 - decomposition using the Daubechies wavelet of the 12th order with decomposition level of $4 ; 3-$ decomposition level is $10 ; 4$ - decomposition level is 14 .

For a shielded cable, the time series of the capacitance are shown in Fig. 8,c; of the dielectric loss tangent - in Fig. 8,d. The curves correspond to: 1 - initial data; 2 - decomposition using the Daubechies wavelet of the 12th order with decomposition level of 4; 3 - decomposition level is 8 .

The presence of the shield causes less noise when measuring the dielectric absorption parameters of the shielded cable and, of course, with a lower value of the decomposition level, more efficient filtering is observed compared to unshielded cable (compare curves 4 and 2 in Fig. 8, $a, b$ and Fig. 8,c,d, respectively).

The reconstructed time series of the dielectric absorption parameters of an unshielded cable (see Fig. 8,a,b) at a decomposition level of 14 are consistent with the average capacitances of $4.909 \cdot 10^{-9} \mathrm{~F}$ and the dielectric loss tangent of 0.001433 [17].

\section{Conclusions.}

Based on long-term measurements, the effect of surface and tribo charges on the results of monitoring the capacitance and the tangent of the dielectric loss angle of power and information cables with polyethylene insulation is established. The scatter of the measured values of the dielectric loss tangent due to the influence of tribo charges can reach three (for newly manufactured) one (aged in operation ones) orders, which makes it difficult to control the state of polymer insulation.

The inefficiency of filtering the spectra of time series using a low-pass filter based on the direct Fourier transform is shown. Significant distortion of the results in the high-frequency region, especially when using highorder filters, has been established.

Using an unshielded cable as an example, a multilevel wavelet expansion of the time series of parameters is presented. The efficiency of applying the wavelet transform to identify high-frequency and lowfrequency components in the measured values is shown. 

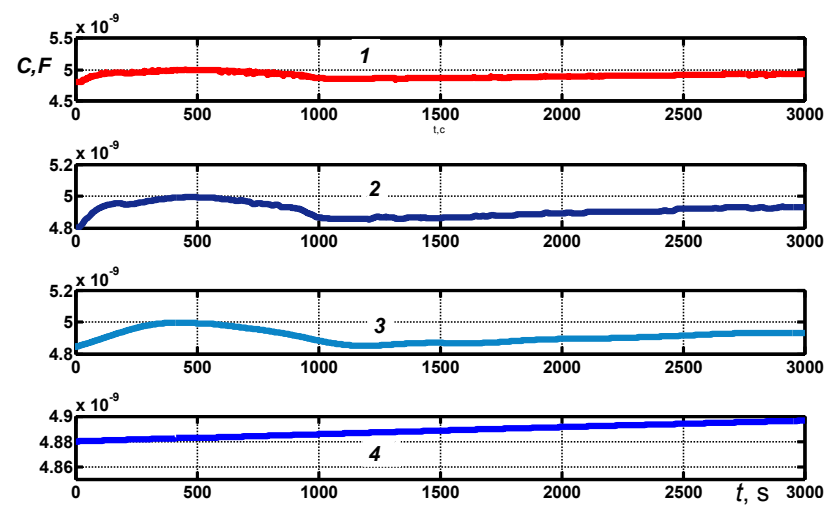

$\operatorname{tg} \delta$

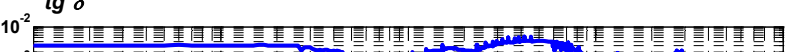

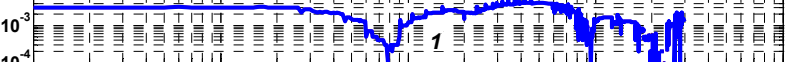
$10_{10^{-4}}^{-4}$

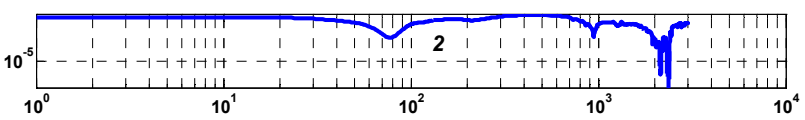

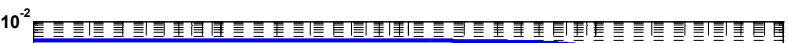

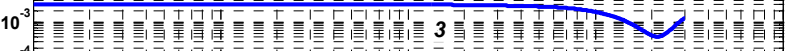

$10_{10}^{-4} \frac{1}{10}$
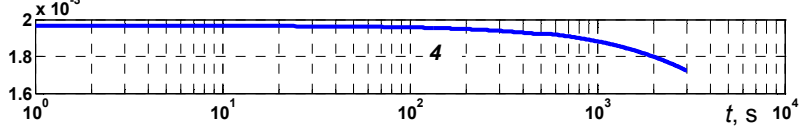

$b$
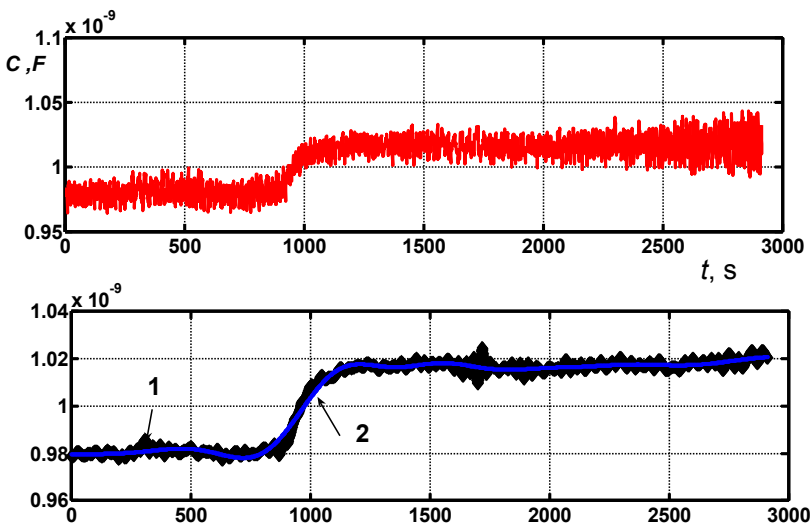

$c$
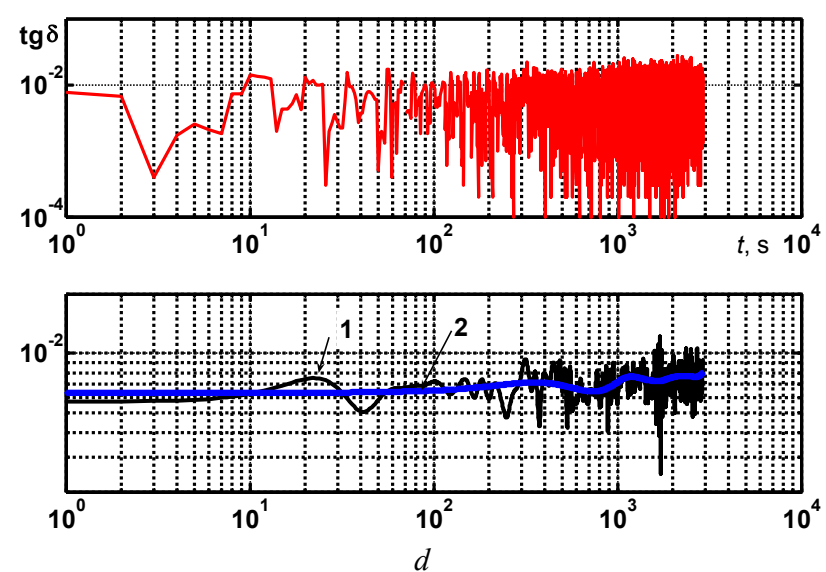

Fig. 8. On the selection of the optimal level of decomposition of the measured values of the dielectric absorption parameters of unshielded $(a, b)$ and shielded $(c, d)$ cables using a 12-order

Daubechies wavelet
The optimal level of decomposition of the measured values of the dielectric absorption parameters of twistedpair cable of unshielded and shielded cables using the 12order Daubechies wavelet is substantiated.

The first proposed method for analyzing the time series of dielectric absorption parameters using wavelet transform allows to increase the accuracy of monitoring and diagnostics of solid polymer insulation, both at the manufacturing stage and in the operation of electrical insulating structures. This method is the basis for creating a database of control results for assessing the state of solid polymer insulation of electrical insulation structures, in particular, power and information cables.

\section{REFERENCES}

1. Kholodny S.D., Serebryannikov S.V., Boev M.A. Metody ispytanii $i$ diagnostiki $v$ elektroizoliatsionnoi $i$ kabel'noi tekhnike [Testing and diagnostic methods in electrical insulation and cable technology]. Publishing House MEI, 2009. 232 p. (Rus).

2. Bezprozvannych G.V., Roginskiy A.V. Dielectric spectroscopy of casing thermosetting composite electrical insulation system of induction traction electric machines. Electrical engineering \& electromechanics, 2018, no.1, pp. 1720. doi: 10.20998/2074-272X.2018.1.02.

3. Bezprozvannych G.V., Kostyukov I.A., Roginsky A.V. Characteristics of cased electrical insulation system of asynchronous electrical machines at resonance frequency. Technical electrodynamics, 2019, no. 4. pp. 48-55. (Rus). doi: 10.15407/techned2019.04.048.

4. Bezprozvannych G.V., Boyko A.N. Substantiation and guaranteeing of technological parameters of triboelectrical method of monitoring of cables with polymer insulation. Electrical Engineering \& electromechanics, 2014, no. 6, pp. 5660. (Rus). doi: 10.20998/2074-272x.2014.6.10.

5. Bezprozvannych G.V., Boyko A.M. Electrostatic processes in power cables. Electrical engineering \& electromechanics, 2013, no.4, pp. 27-31. (Ukr).

6. Bezprozvannych G. V., Boyko A.M. Experimental determination of triboelectric potential in unshielded and shielded network cables. Electrical engineering \& electromechanics, 2012, no. 3, pp. 56-60. (Ukr).

7. Bezprozvannych G.V., Boyko A.N. Contact potential difference as a measure of power cable polymer insulation aging. Electrical engineering \& electromechanics, 2014, no. 5, pp. 62-66. (Rus). doi: 10.20998/2074-272x.2014.5.12.

8. Bezprozvannych G.V., Boyko A.N. Distribution of surface density of charges on the interface between contacting isolated conductors of the cables. Technical Electrodynamics, 2014, no.6. pp. 18-23. (Rus).

9. Ango A. Matematika dlja elektro- $i$ radioinzhenerov [Mathematics for electro- and radioengineers]. Moscow, Nauka Publ., 1965. 780 p. (Rus).

10. Korn G., Korn T. Spravochnik po matematike dlia nauchnykh rabotnikov i inzhenerov [Mathematical handbook for scientists and engineers]. Moscow, Nauka Publ., 1977. 830 p. (Rus).

11. Sergienko A.B. Tsifrovaia obrabotka signalov [Digital signal processing]. St. Petersburg, BHV Publ., 2011. 768 p. (Rus).

12. Potemkin V.G. Sistema MATLAB [MATLAB System]. Moscow, DIALOG-MIFI Publ., 1998. 350 p. (Rus). 
13. Dyakonov V.P. MATLAB i SIMULINK dlia radioinzhenerov [MATLAB and SIMULINK for radio engineers]. Moscow, DMK Press Publ., 2011. 976 p. (Rus).

14. Malla S. Veivlety v obrabotke signalov [Wavelets in signal processing]. Moscow, Mir Publ., 2005. 671 p. (Rus).

15. Fraser $\mathrm{M}$. Vvedenie $v$ veivlety $v$ svete lineinoi algebry [Introduction to wavelets in the light of linear algebra]. Moscow, BINOM. Laboratory of Knowledge Publ., 2010. 487 p. (Rus).

16. Daubechies I. Desiat' lektsii po veivletam [Ten lectures on wavelets]. Izhevsk, SIC «Regular and chaotic dynamics» Publ., 2001. 464 p. (Rus).

17. Bezprozvannych G.V., Kostiukov I.A. Error of control of electrical insulation structures by dielectric absorption parameters according to the concept of uncertainty of measurements. Electrical engineering \& electromechanics, 2020, no.1, pp. 47-51. doi: 10.20998/2074-272X.2020.1.07.

Received 12.12.2019
G.V. Bezprozvannych ${ }^{1}$, Doctor of Technical Science, Professor, I.A. Kostiukov ${ }^{1}$, Candidate of Technical Science,

${ }^{1}$ National Technical University «Kharkiv Polytechnic Institute», 2, Kyrpychova Str., Kharkiv, 61002, Ukraine, phone +380 577076010 , e-mail: bezprozvannych@kpi.kharkov.ua, iakostiukow@gmail.com

\section{How to cite this article:}

Bezprozvannych G.V., Kostiukov I.A. A method of wavelet analysis of time series of parameters of dielectric absorption of electrical insulating structures. Electrical engineering \& electromechanics, 2020, no.2, pp. 52-58. doi: 10.20998/2074-272X.2020.2.08. 